\title{
The Hunt for an Eternal Legacy: Putin and the Vampire Legend in Modern Russia
}

\author{
Colleen Lucey \\ University of Arizona \\ Tucson, AZ, USA
}

\author{
Melissa Miller \\ University of Notre Dame \\ Notre Dame, IN, USA
}

\begin{abstract}
Today's image of the vampire in Russia is a fascinating case study in how people both bring Slavic folklore to life in the digital age and how they make use of developing technologies to participate in political protest. For instance, online commentators and political cartoonists portray Russia's current president, Vladimir Putin, as a modern-day vampire who feeds on the dual policies of expansionism and political repression. On the other hand, his uncanny ability to avoid the signs of aging bolsters his hold on power and further aligns Putin with the vampire and the character's subsequent iterations in popular culture. Using the vampire to convey political and social anxieties predates Putin's presidency. Given the vampire's possession of taboo knowledge and its ability to wreak havoc on communities, the figure appears as a simulacrum for a politically savvy, yet heinously unjust, ruler. From the tyrannical Vlad Dracula (1431-1476) who impaled his advisories, to the display of Vladimir Lenin's (1870-1924) embalmed, seemingly "undead" body on Moscow's Red Square, longevity of the state has paralleled the search for ultimate sovereignty, both in life and in death. This article examines a variety of folktales, fiction (including Stoker's Dracula and Pelevin's Empire $V$ ) and media (including film and memes). We argue that the supernatural in modern Russia in the form of the vampire legend performs paradoxical functions, in that it both serves to legitimize the autocratic state, while at the same time is weaponized (by journalists, artists, Internet users) to critique the Putin regime.
\end{abstract}

\author{
"Unfortunately, he is a vampire." \\ -Liudmila Putina describing her husband Vladimir Putin
}

In the summer of 2008, the Russian tabloid Tainy zvëzd [Secrets of the Stars] featured a youthful, smiling Vladimir Putin on its cover (Figure 1). The issue created a frenzy at kiosks 


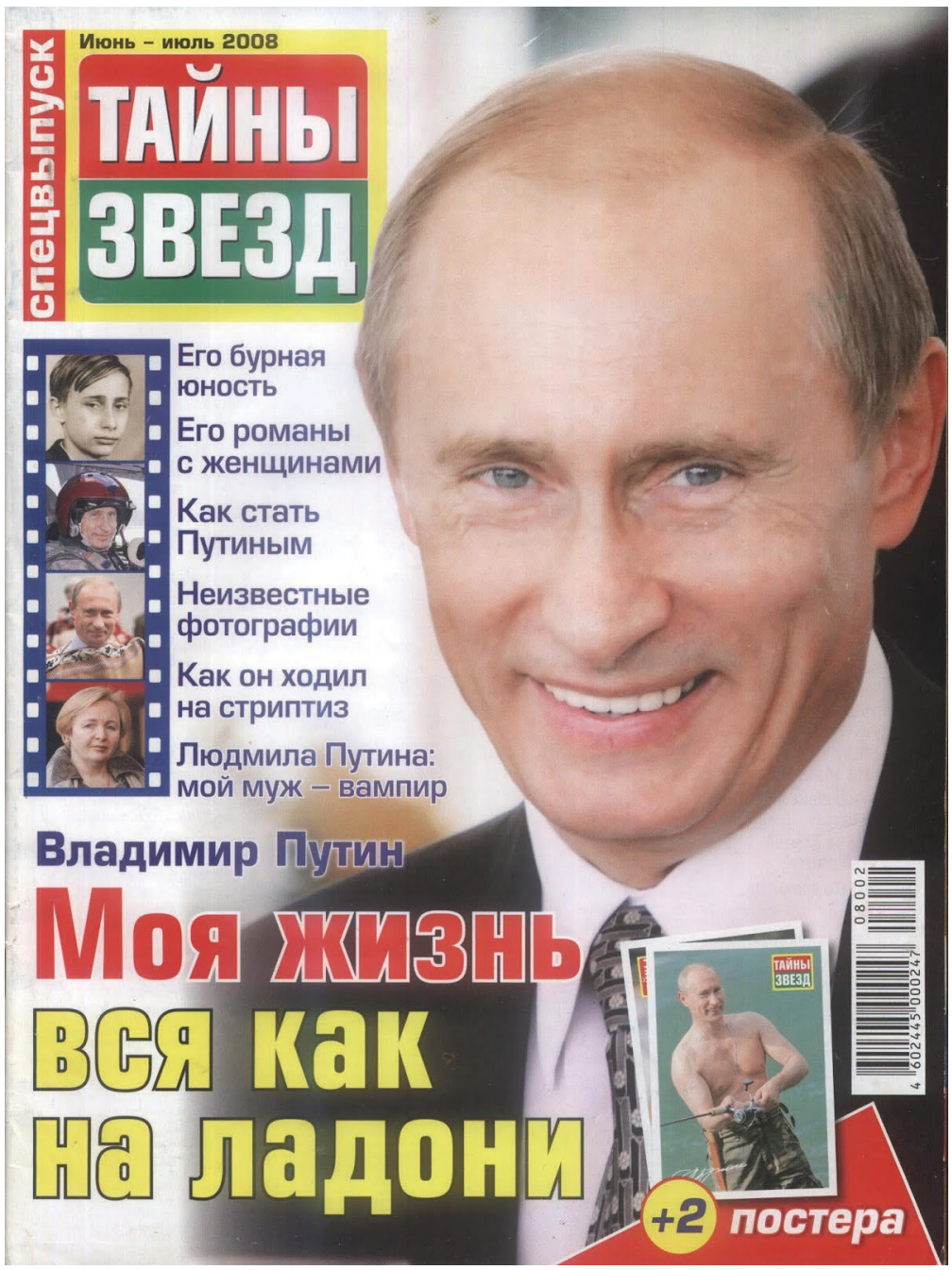

Figure 1: Image reproduced courtesy of Baner Media Group, Russia.

around the country, setting a new sales record as the Russian public eagerly purchased available copies. What drove citizens from all parts of the country to buy this particular tabloid? Certainly, it promised titillating reading material: unpublished photos of the president; provocative details on his past relations with women; and two pin-up posters of a topless Putin to share with friends and family. But one cover story likely caught the eye of potential buyers - an exposé from none other than the president's wife, Liudmila Putina. According to the tabloid, she had shocking news to share with the public: her husband was a vampire. 


\section{Modern Russia}

Media outlets in Europe and North America found Liudmila Putina's description eerily precise. The accusation seemed oddly appropriate; like the vampires of Slavic folklore and popular culture, Putin never aged. He seemed undaunted, if not invigorated, by political battles both at home and abroad. Putin's vampirism remained a heated question, as the same Russian tabloid revisited the question in 2011, with a photo of Putin pointing two fingers by his mouth with an accompanying caption by Liudmila, "My husband is a vampire!" (Figure 2).

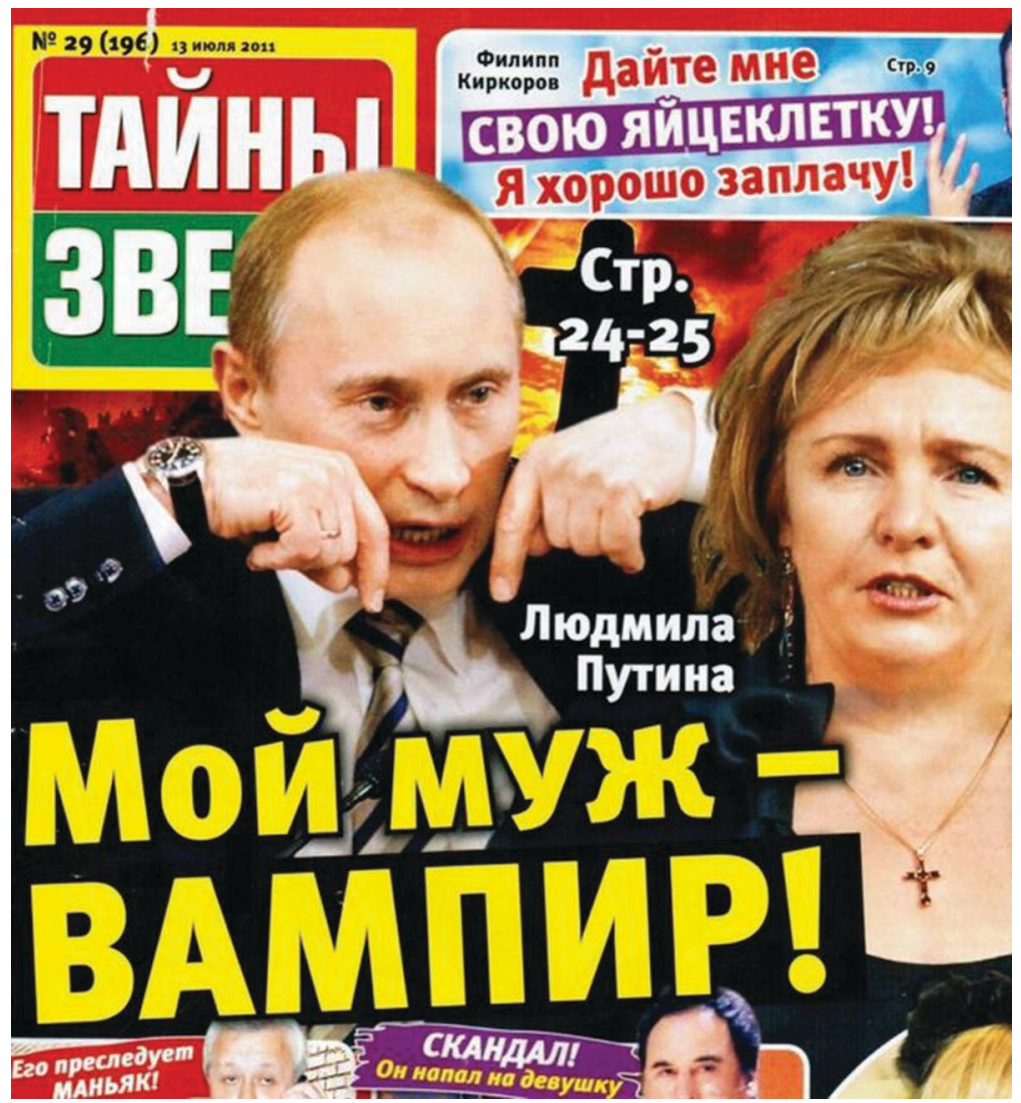

Figure 2: Image reproduced courtesy of Bauer Media Group, Russia.

Conspiracy theorists and comedians alike churned out racy and shocking stories that explained Putin's political prowess as a kind of psychic vampirism that threatened the global community. Such charisma allowed him "to bleed" his foes of energy while simultaneously endearing him to Russian women who found his virility irresistible [Cassiday and Johnson 2010]. As Liudmila Putina put it, "He never beat me, but he sucked the juices right out of me."

The president's ex-wife (they divorced in 2013) and subsequent commentators looked to the figure of the vampire to explain Putin's uncanny hold 
on everything from the Russian people's state of mind to hacking the 2016 American presidential election. In fact, the mythologization of Putin as 21 stcentury blood-sucker registers with audiences both in Russia and abroad because it taps into a well-established image of the East European vampire who travels West in his insatiable hunger for power. Immortalized in works like Bram Stoker's Dracula (1897) and F.W. Murnau's silent film classic Nosferatu (1922), these many faces of the Eastern vampire demonstrate that "our fascination with vampires is undying; their popularity, inexhaustible" [Hudson 2017:2]. Like these vampires from fiction and film, Putin possesses an ability to "hypnotize" the West with his reputation as a strong, autocratic ruler who defeats enemies both on domestic and foreign fronts. As Valerie Sperling has noted, formulating an image of himself as invincible plays a central role in Vladimir Putin's "political legitimation strategy" and the justification of increasing authoritarianism in today's Russia [Sperling 2015:29].

In this article, we outline how the vampire has evolved from its roots in Slavic folklore to its prominence in contemporary fiction and film. We argue that the supernatural, in the form of the vampire legend, performs paradoxical functions in contemporary Russia, in that it both serves to legitimize the autocratic state, while at the same time is weaponized (by journalists, artists, Internet users) to critique the Putin regime. The figure of the vampire resonates in today's Russia as a simulacrum for a sovereign ruler who blends cruelty and charisma in ways that confound the West. (1) From the tyrannical Vlad Dracula (1431-1476) who impaled his adversaries and then reportedly drank their blood, to the display of Vladimir Lenin's (1870-1924) embalmed, seemingly "undead" body on Moscow's Red Square, East European leaders strive for sovereignty both in life and death. Within this context, Russian artists have turned to Stoker's Dracula as a rich source text to explore the image of the vampire in Putin's Russia. Contemporary Russians grasp the otherness of Stoker's Eastern Count-who audaciously challenges British hegemony-within their own nation's "outsider" status on the world stage. Just as important for the Russian cultural imagination is the complex relationship between technology, power, and the occult outlined in Stoker's novel. Subsequent iterations in fiction and film explore the rich complexities inherent in the vampire figure, noting the role of supernatural forces in the establishment of a leader's political power.

Buckets of blood: mobilizing the folkloric vampire in vernacular settings

While contemporary iterations of the vampire in Russian culture suggest strong affinity with Stoker's Dracula, it would be an oversight not to recognize the importance of Slavic folklore as the generative source from which past and present representations of the vampire have evolved. Of course, the vampires of popular culture like those in the series Twilight, with their sparkly skin and vegetarian impulses, are far removed from the flesh-eating, blood-drinking creatures of Slavic folklore. Despite their obvious differences, modern conceptualizations of the vampire can be traced to folklore from Central and 


\section{Modern Russia}

Eastern Europe [Garza 2010: 1-3]. This deep folkloric past resonates with contemporary depictions of Vladimir Putin as a vampire. When, for instance, Liudmila Putina stated that her husband "sucked the juices right out of her," she may not have consciously known that the characterization of her husband did, in fact, align with descriptions of vampire behavior found in Slavic folklore. Jan Perkowski, one of the first scholars to study Slavic conceptualizations of the vampire, defines a vampire as a "being which derives sustenance from a victim, who is weakened by the experience. The sustenance may be physical or emotional in nature" [Perkowski 1976: 136]. In contrast to modern depictions of the vampire, which showcase their willingness to feed off anyone, the creature of Slavic folklore prefers the blood of its closest relatives. According to Felix Oinas, vampires in Slavic folklore "always visit relatives first, particularly their marital partners" [Oinas 1998: 48]. Thus, Putin feeding off his wife symbolically links him to the Slavic narrative tradition.

There are additional ways in which contemporary representations of Putin draw upon vernacular beliefs to underscore his similarity to a vampire. In some modern conceptualizations, Putin is depicted as a magnetic leader with special powers that he can use to bewilder leaders of state and citizens of his country. Stories like the 2003 article from Komsomol'skaia pravda titled, "Does Putin defend the power of sorcery?" claim that Russia's political leaders frequently turn to magicians and fortune tellers to protect themselves against the evil eye and other forms of black magic [Komsomol'skaia pravda 2003]. Indeed, superstition and the power of the occult continue to play an important role in contemporary Russian political life as seers, fortune tellers, and astrologers make the line-up on numerous Russian TV shows to offer their predictions on domestic and foreign affairs. As Mariya Lesiv convincingly shows in her study on the role of the supernatural in Ukrainian and Russian vernacular and media contexts, while it may seem perplexing to outsiders, "the supernatural is incorporated into the highest-level political discourses" in Eastern Europe [Lesiv 2018: 35]. As she explains,

In Eastern Europe, and in Ukraine and Russia in particular, the supernatural is not in need of defense from the perceived progressive science-based paradigm of thinking. Rather, it constitutes part of this very paradigm, having even been incorporated into scientific research. In other words, in Ukraine and Russia, the supernatural does not stand in opposition to modernity but occupies a position that is often diametrically opposite to 'backward'. [Lesiv 2018: 47]

Lesiv's study, which in part focuses on how state institutions incorporate supernatural beliefs to legitimize their political and social platforms, proves useful in our analysis of the vampire legend in contemporary Russia. We argue that the supernatural, as represented in the vampire, is mobilized to explain Putin's political prowess, while also utilized to critique autocracy. 
Contemporary discourse on the role of supernatural forces in everyday life can be traced back to folkloric texts, where we find the vampire imagined as an entity connected with sorcery, witchcraft and heresy. As Oinas explains, in Slavic folk traditions "the same person who in his lifetime is called koldun [sorcerer] is called eretik [heretic] after his death if he roams around at night in villages, captures people, and eats them" [Oinas 1998: 53]. The first recorded collection of Russian folktales, assembled by the ethnographer Aleksandr Afanas'ev in the nineteenth century, feature such beings. For example, in the folktale "The Vampire" the heroine, Marusia, witnesses her vampire-suitor eat the flesh of a corpse that is housed in a church, presumably for an upcoming burial [Afanas'ev 1975: 593-8]. When the vampire confronts Marusia, she denies witnessing the crime; as punishment, he uses sorcery to kill her family members one by one. While the contemporary image of vampirism always involves drinking blood, the Slavic tradition does not, as this tale demonstrates. The vampire consumes the flesh of humans and is a sorcerer, as Oinas describes. Some of the character traits that the vampire displays in this folktale - excessive cruelty, the ability to harness black magic to live post-mortem, torturing a victim through psychological warfare - extend into modern-day iterations of the legend and depictions of Putin.

In contemporary culture, Putin's dominance in world politics has produced a rich assortment of stories profiling his supposed supernatural capabilities. Depending on the source, Putin's talent to bend the will of international leaders is interpreted either as confirmation of his destiny to rule Russia or, conversely, proof of a dangerous magnetism that threatens world order. In the West, politicians and comedians alike have pointed to Putin's "psychic hold" over American leaders. While contemporary discussions focus on relations between Putin and Donald Trump, it is worth noting that the Russian president's magnetism was observed as early as 2001 when he first met then US president George H. Bush. "I looked the man in the eye," Bush explained, and "I was able to get a sense of his soul." Bush was so enamored by Putin's charming gaze that he invited the Russian leader to his Texas ranch. "I wouldn't have invited him to my ranch if I didn't trust him," Bush touted to reporters. (2) Putin's ability to captivate American presidents has resurfaced in recent years, especially in the controversy surrounding Russia's interference in the 2016 presidential race and Trump's subsequent win of the White House. Shortly after the 2016 election, Stephen Colbert featured a segment where he interviewed the cartoon version of Trump, only to have a cartoon Putin appear whispering answers into the new president's ears [The Late Show with Stephen Colbert 2016.]. The skit, which hinted at hypnosis from the beginning, culminated in Trump falling into a Putininduced trance. Declaring the studio too hot for his liking, Putin rips off his shirt to reveal finely chiseled pecs and abs, and turning to Trump says, "Donald, stare into my hypno-pecs." Trump's cartoon eyes turn various shades of psychedelic colors as he becomes entranced with Putin's chest and repeats after the Russian president: "You are trusting me. We are your allies. You give me Alaska. And you will hand over Moose and Squirrel." They then "seal the deal" with an "openmouth sonnet" and proceed to lock tongues in a slimy exchange. 

Modern Russia

While Western comedians have poked fun at his "supernatural" ability to hypnotize Trump, Russian media outlets have utilized astrologers to confirm the Russian president has a divine destiny. The documentary produced by the Russian TV station REN in 2013 focuses on the life and prophecies of the famous Bulgarian seer Vanga (1911-1996), well-known both in Eastern Europe and abroad [REN 2013]. Her predictions widely circulate online and in the media as confirmation of everything from the 9/11 terrorist attacks, to Obama's presidency, and Brexit [Crouch 2018]. Particularly relevant to our discussion of Putin are statements Vanga made in 1979 to the writer Valentin Sidorov about the "glory of Vladimir." Vanga's prediction that "everything will melt away like ice-and only one thing will remain untouched - the glory of Vladimir, the glory of Russia," has been used as proof in online commentaries, news stories, and sensational documentaries that Putin was destined to be president of Russia [Evlampiev 2018; Lesiv 2018: 34; REN 2013]. (3)

Another connection between modern depictions of Putin and the vampire legend of Slavic folklore is, of course, the Russian president's ability to defy the signs of aging. This, too, can be traced back to themes in folklore. Tales collected by Afanas'ev feature vampires that drink large quantities of blood not only to sustain life beyond the grave but to blend in with the population. In the tale "Bucket of Blood," for example, a stranger approaches a peasant asking for a ride into the village. Unable to enter any houses where a crucifix is present, the vampire tricks the peasant into stopping at a cottage with no Christian insignia. As the peasant waits in the carriage, the vampire accosts an old man and boy, stabs them in the back, drains them of their blood and drinks an entire bucket full [Perkowski 1989: 21-2]. The peasant is saved from being the vampire's next victim only thanks to the cock's crow, which vanquishes the evildoer. This tale, like many others, confirms that the vampire may feed on blood in order to remain appealing to community members. As we discuss below, the consumption of blood will factor into modern perceptions of Putin as a vampire. Specifically, commentators both in Russia and abroad have pointed to rumors that Putin bathes in the blood of Siberian red deer, famous for their blood's supposed mystical power to rejuvenate and prevent the signs of aging [Pleitgen 2018; Filonov 2017].

Folkloric texts like "The Vampire" and "Bucket of Blood" describe the primary methods of repelling vampires (garlic, crucifixes, and holy water) as well as the means of killing them (a stake through the heart, sunrise). These apotropaics - some of which draw from Christian tradition, others from preChristian beliefs - affirm what scholars widely describe as dvoeverie, a "dual belief" system present in Slavic cultures [Kononenko 2007: 6]. To be sure, ethnologists and folklorists have complicated the traditional understanding of dvoeverie by expanding the frame of reference and accounting for inherent contradictions in belief practices [Levin 1993; Worobec 2006]. In the context of this article, we contend that contemporary Russian cultural production maintains its postmodern flair through the act of appropriating conflicting discourses, including references to pagan and Christian religious beliefs, to create explosive visions of present-day reality through the vampire mythos [Lipovetsky 2017]. 
Critics of Vladimir Putin, for example, have turned to medieval history, particularly the reign of Vlad the Impaler, in their vision of the Russian president.

A tale of two Vlads: Vlad the Impaler and Vlad(imir) Putin

News outlets and online commentators heighten the perception of Putin as a cruel and cunning leader by painting him as a twenty-first century reincarnation of a different Vlad, namely the medieval ruler Vlad Tepes III, commonly referred to as Vlad the Impaler or Vlad Dracula. While these iterations meld the image of Vlad Dracula, vampirism, and Putin, it should be noted that in the East European folklore tradition there are no examples of the historical Vlad Dracula behaving as a vampire. While one woodcut print from the medieval period shows him feasting in the company of impaled enemies (Figure 3), the belief that Vlad Dracula drank the blood of victims is a modern-day invention originating from Western sources.

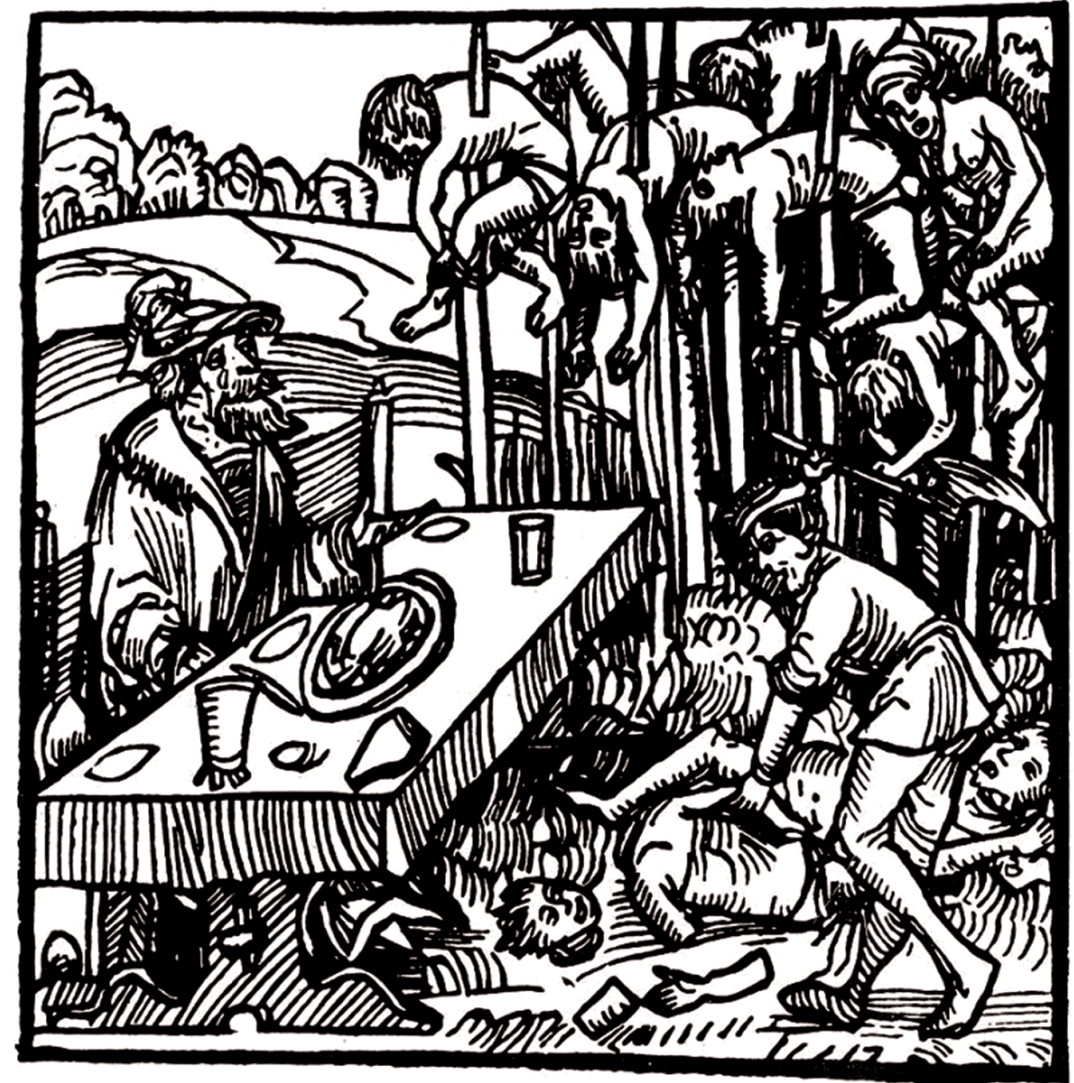

Figure 3: 1499 German Woodcut depicting Vlad Dracula dining in the company of recently impaled victims. Image source Wikipedia Commons. 


\section{Modern Russia}

The perception of the historical Vlad Dracula as a vampire emerged after Bram Stoker's iconic depiction in Dracula. However, as Elizabeth Miller convincingly shows, Stoker had very limited knowledge of the Wallachian leader's biography. What Stoker did know about the medieval ruler he gleaned from a description he read in William Wilkinson's 1820 Account of the Principalities of Wallachia and Moldavia that outlined the brief successes of the "voivode" named Dracula. "What compelled Stoker to use the name "Dracula," explains Miller, is Wilkinson's footnote: "Dracula in the Wallachian language means Devil" [Miller 2000: 188-190]. (4) While popular culture has pointed to Stoker's Dracula as "proof" that the writer used the medieval ruler as inspiration for his vampire character, in fact, various scholars and commentators of the novel proposed this interpretation. The supposed connection between Vlad Dracula and Stoker's vampire count has become so pervasive that it has supplanted traditional beliefs in modern Slavic and East European contexts. Thus, we see that while the vampire legend has its origins in Eastern Europe, contemporary iterations in Slavic and East European culture draw upon Stoker's Dracula as referent, not necessarily the traditional beliefs outlined by Oinas, Afanas'ev, and Perkowski.

In most instances, Western journalists use the reference of Vlad the Impaler when referencing Putin to create a comedic effect, like the $2012 \mathrm{New}$ York Post story "Vlad the Impaler: Putin may have had an affair with ex-spy Chapman." In the digital realm, such stories mobilize the image of Vladimir Putin as an "Impaler" (clearly a phallic symbol) to underscore his virility, oftentimes producing raunchy results latent with misogynistic imagery. More nuanced critique can be traced to political cartoons, which likewise play with the association by drawing out the connection between the two "Vlads" (Figure 4). A 2014 image by the popular cartoonist Joe Heller juxtaposes "Vlad the Impaler," who is dressed in traditional garb and holding a sharpened stick, to "Vlad the Annexer," an emotionless Vladimir Putin grasping a pencil in one hand and holding a map with a large " $\mathrm{X}$ " over Crimea to signify its status as a new addition to the Russian nation. 


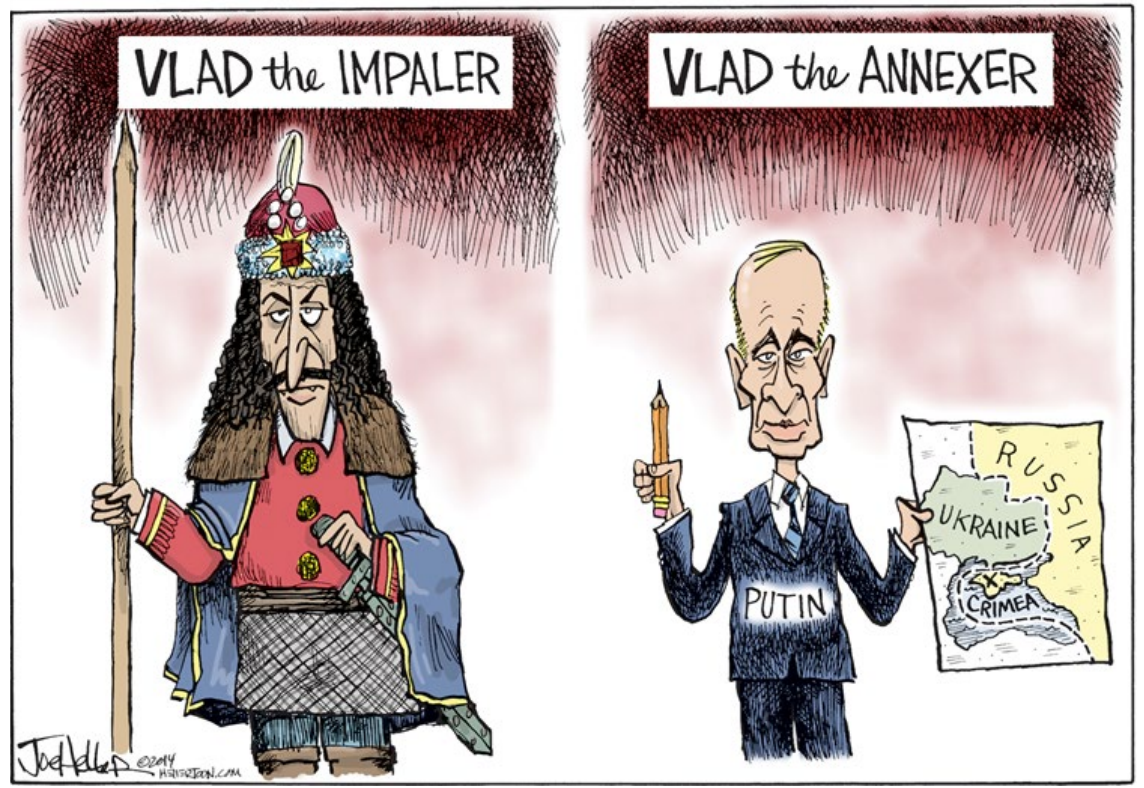

Figure 4: Image reproduced courtesy of Joe Heller, Editorial Cartoonist.

There is more than just the similarity in name that draws the parallel between Vlad the Impaler and Vladimir Putin. Like his medieval predecessor, Putin has acquired a reputation for ousting combatants and squashing dissent. Moreover, the Russian president seems invincible and impossible to outmaneuver, recalling Vlad the Impaler's incredible ability to side-step danger. For example, when the Wallachian forces under his leadership led a surprise attack against the Ottoman Turks in June 1462, it was reported that Vlad Dracula went under cloak of darkness into the enemy camp to conduct the necessary reconnaissance to locate the tents of Sultan Mehmed II's viziers Mahmud and Ishak [Cazacu and Reinert 2017; 148-9]. Although the Ottoman troops weathered the attack and the Wallachians eventually retreated, Vlad Dracula successfully terrorized his foes and sparked fear among the Turkish forces. Putin not only conjures up an association with Vlad Dracula because of his supposed military prowess, but because he seems forever young. Tabloids both in Russia and abroad point to Putin's remarkably unwrinkled face and sculpted physique as proof the president might very well be Vlad the Impaler in the flesh. A popular article first published by the Daily Mail and later re-circulated in Russian by the Kremlin-funded news outlet Russia Today, proposed that "Putin was born in 1431" and is none other than "the Wallachian Prince Vlad Tepes, better known as Count Dracula" [Spargo 2015].

The references in popular culture connecting Putin with Vlad the Impaler metaphorically link the two because they supposedly share a sadistic love of torture. It is worth explicating Vlad the Impaler's legacy in order to better situate 


\section{Modern Russia}

this connection. Although his ancestry was Romanian, not Slavic, Vlad the Impaler and the subsequent lore devoted to his life nevertheless drew from (and subsequently influenced) Slavic portrayals of the vampire [Garza 2010: 1]. The epithet "Dracula the Impaler" comes from the ruler's proclivity for sadistic means of torture, including (but not limited to): disembowelment, forcing mothers to eat their children, lighting the poor and crippled on fire, and most notably, impalement [Cazacu 2017: 200-205]. This latter form of torture he perfected to ensure the victim "was not immediately killed, but would die of thirst after two or three days, his eyes eaten out by crows, but still in possession of all his senses." Moreover, "Dracula had planted a forest of stakes, three kilometers long and one kilometer wide, right before his palace windows so he might comfortable contemplate the convulsions of this victims" [Cazacu 2017: xvi]. Dracula compounded his cruelty with cynical wit, often testing travelers and ambassadors with questions that would mean a painful and agonizing death if they failed to answer correctly. The Russian account of Vlad Dracula from 1486, Skazanie o Drakule voevode [The Tale of Voievod Dracula] likely authored by the Russian ambassador, Fedor Kuritsyn, describes how Vlad punished Turkish dignitaries who arrived to his castle and forgot to take off their hats; when they explained this was not their custom, Vlad responded: "Very well, I shall strengthen you in your custom. Brace yourselves!" and nailed their turbans to their heads.

The Tale of Voievod Dracula proves interesting not only for its detailed account of Vlad's atrocities, but because of its interpretation of the Romanian ruler as a fair and just sovereign. Not unlike the Court of Ivan the Terrible, Vlad Dracula had to defend his country against threats and saboteurs, from both within and without. The text thus justifies Vlad's cruelties as a necessary measure to ensure law and order. Vlad's logic, as interpreted by the text's author, is that of divine sovereignty; a ruler, in this sense, follows Saint Peter's magnate that the emperor "as supreme authority" governs "as commissioned by him to punish criminals and praise good citizenship" [Peter 2:13-15]. This particular form of pragmatism could equally describe Putin's political platform, which has garnered him immense success at home, at least until recently. While no public tortures have accompanied Putin's rise to power, other modes of attack - his popular campaign against the detested oligarchs in the $90 \mathrm{~s}$, his treatment of dissidents, allegations that he orchestrated assassinations of political enemies, and his successful outwitting of international leaders - symbolically link him in popular culture to Vlad Dracula. Furthermore, as Helena Goscilo argues, "several aspects of Putin's persona actually facilitated his construction as a masculine icon incarnating the wise ruler who seamlessly unites the warrior and the thinker" [Goscilo 2012: 184]. Putin's mental and physical alertness combined with his expertise in espionage links him not only to Vlad the Impaler, but to Stoker's iconic depiction in Dracula.

Bram Stoker's Dracula — a slick Russian from Transylvania 
The vampire legend in Slavic culture is a fascinating case study in how people both bring the literary text of Bram Stoker's Dracula (1897) to life in the digital age and how they make use of developing technologies in order to participate in political protest. The enduring relevance of Stoker's legacy in the West cannot be denied. Along with Mary Shelley's Frankenstein and Robert Louis Stevenson's The Strange Case of Dr. Jekyll and Mr. Hyde, Stoker is remembered as "the author of one of the three most celebrated horror stories in the history of English literature" [Stoker 1996: 410]. Moreover, Stoker's novel has spawned countless film, theatrical, and literary adaptations. The story famously follows a hapless young solicitor named Jonathan Harker, who has been sent by his employer to Transylvania to meet with a venerable and wealthy client by the name of Count Dracula. Harker soon realizes the nefarious nature of the Count's business and tries to escape his forced captivity at the hands of the Count. When Harker finally succeeds in freeing himself, he discovers that the Count has, in the meantime, visited England and infected his fiancé's friend Lucy with vampirism. Harker then joins Dr. Van Helsing, three friends, and his wife Mina on an international hunt in order to capture Dracula and rescue Mina, who has also been infected, from the vampire's hold.

Despite the novel's enduring popularity in the English-speaking world, scholars have yet to satisfactorily explore the impact of the Dracula legend on modern Russian literature and culture. This lacuna is somewhat surprising, given both that Stoker's work is widely available in Russian translation, in both print and digital forms, as well as the particular nature of Stoker's creation itself. We may begin by noting the remarkably Russian nature of Stoker's vampire, for in this classic text, the epitome of suave, slick vampiric evil is embodied in the form of a Russian Slav. As Jimmie E. Cain, Jr. notes in his study Bram Stoker and Russophobia: Evidence of the British Fear of Russia in Dracula and The Lady of the Shroud, "Dracula's heritage suggests clear Russian and Slavic antecedents" [Cain 2006: 120]. While Cain cites numerous examples which point to Dracula's Russian genealogy, such as the fact that Stoker's vampire calls himself by the hereditary title of boyar, originally the Russian term for a landed nobleman, whose usage later migrated to Romania, the main focus of his study is to demonstrate how Dracula's Slavic features betrayed an English anxiety towards Russia as a formidable threat to the territorial integrity of the British Empire during the nineteenth century. By contrast, the present study's goals are twofold: not only are we interested in how Stoker uses these Russian tropes in order to construct his narrative, but also, we will investigate how Russians themselves have been inspired by Stoker's canonical work. In this connection, we show how key Russian allusions in Stoker's text propel the plot forward, as well as demonstrate the ways in which Stoker's Russian readers and fellow writers have adapted his devices in order to protest the current regime under Putin.

Perhaps the primary reason that the novel's Russian themes remain understudied is that some of the most important Russian references occur in a section of the book entitled "Dracula's Guest," which has been considered controversial on textological grounds. It was once commonly assumed that 

Modern Russia

"Dracula's Guest" was intended to be part of the book's second chapter but was excised from the original publication due to the manuscript's length. This section was first published at the behest of Stoker's widow Florence in 1914, two years after his death, in a volume called Dracula's Guest and Other Weird Tales [Stoker 1996: xix]. However, Dracula scholars Elizabeth Miller and Clive Leatherdale have convincingly argued that "Dracula's Guest" is not an excised chapter from Dracula, but rather, an early sketch or short story Stoker wrote as he was developing his novel [Miller 2000, 131-135; Leatherdale 1998, 138-154]. If we consider this section as having laid important groundwork for the complete text of Dracula as it is accepted today, the novel's Russian themes become quite salient. Not only does this section's ties to Russian culture encapsulate a major theme of the novel, but it also affords primary importance to the Russian language itself, as well as to the massive power it contains. In this section, the narrator, who only in later versions of Stoker's tale officially becomes Jonathan Harker, is on his journey to the Count's castle, and he wishes to visit a curious village that he has heard about. When his driver refuses to take him to this mysterious place, the narrator sends him away and sets out himself on foot. Once he arrives, a formidable storm breaks out, forcing him to seek refuge. The only structure he can find is a "great massive tomb of marble" [Stoker 1996: xxx]. Once he enters, a flash of lightning treats him to an arresting sight, that of "a beautiful woman, with rounded cheeks and red lips, seemingly sleeping on a bier" [Stoker 1996: xxxi]. However, at this moment something forces the narrator out into the storm once again. He loses consciousness, only to be awoken by a terrible wolf attacking his throat. At the last possible moment, he is saved by a band of local cavalry. As Cain points out, this scene is replete with allusions to Slavic vampire legends, but the most important feature is what the narrator sees inscribed on the tomb: the message "the dead travel fast" which was "graven in great Russian letters" [Stoker 1996: xxx]. Cain, though, does not analyze this inscription further, instead shifting his argumentation towards Russian-British military conflict in the Crimea and Central Asia.

However, these haunting words are worth further study, not least because they cause the narrator to rethink the prudence of his journey and provide the first indication that all is not what it seems. Moreover, the fact that Stoker chose to indicate that these words were inscribed on the tomb in Russian is quite significant. The source for this phrase is actually a repeated line in a macabre German poem entitled "Lenore" by Gottfried August Burger [Stoker 1996: 375]. Carving them on his literary tomb in Cyrillic letters, then, is Stoker's own purposeful invention, and it establishes the rapid movement of evil which animates the novel's plot-the quicksilver speed with which vampires routinely attack their victims, the split-second flight with which Dracula is able to leave his mountain fortress to seek his prey — as being quintessentially Russian. This theme is then continued throughout the rest of the completed novel. For example, Dracula's voyage from Transylvania to England, where he will resume his sanguine rampage, is also figured as a uniquely Russian brand of motion. When the vessel comes into port, conspicuously helmed by a dead man, she is 
recognized by eyewitnesses to be of Russian construction. She also boasted a Russian crew with authentic names, such as Petrofsky and Abramoff, who all mysteriously ended up as dead as their captain. The ship's doom is inextricably linked to her perilous alacrity: English bystanders report that, when the ship was approaching the shore, she "was rushing with such speed that...she must fetch up somewhere, if it was only in hell" [Stoker 1996: 79]. To complete this image of hellish frenzy, as soon as the ship crashes on the shore, Dracula himself, now in dog form, "sprang up on deck from below, as if shot up by the concussion [of the sea], and running forward, jumped from the bow onto the sand and...disappeared in the darkness" [Stoker 1996: 80]. In sum, Stoker drew on two Eastern European images, the Romanian warlord Dracula who was recast, in light of the contemporary dominant power in the Crimean conflict, as a Russian boyar.

Curiously, it is not only Dracula and his many incarnations that move with lightning speed in the novel. Modern technology, too, is described as moving so fast as to be unsettling to the point of losing consciousness. Later on in "Dracula's Guest" we discover that the narrator was saved by the mounted troops only because of a miracle wrought by the day's cutting-edge technology, that is, a telegram sent by Count Dracula to local law enforcement, stressing the danger the narrator presently found himself in and to beg for his safe rescue. Upon receipt of this missive, the troops set out at once for the village. As he explains to the reader, "From a distant country had come, in the very nick of time, a message that took me out of the danger of the snow-sleep and the jaws of the wolf" [Stoker 1996: xxxvi]. But the very fact that Dracula was able to send such a telegram, essentially defying the usual limitations of space and place, is so uncanny and impossibly chilling that the narrator falls into a dead faint and afterwards even claims to have suffered a kind of paralysis. In this way, the text both acknowledges the helpfulness and utility of modern technology, for the telegram saved the narrator's life, while at the same time portrays the speed at which characters can now share information as fearsome and even supernatural. As we will see, this dual nature of technology will be both explored and exploited by Russian artists in their adaptations of the vampire legend in the digital age, as well.

Russia's postmodern vampires: body maintenance and global commodification

Although not nearly as pervasive as in American popular culture, the image of the bloodsucking corpse who feeds on the living emerges in contemporary Russian literature, film, and art. A particularly rich source of such imagery has proven to be artistic renderings of Russian political leaders. As we will explore in more detail below, depictions of Vladimir Putin as vampire continue to dominate the media landscape, both at home and abroad. However, in order to understand modern iterations of the vampire legend in Russia, we must first examine the country's Soviet past.

This merging of the vampiric imaginary and the political in Putin's Russia actually has its roots in the Soviet era, owing to the innovative, yet macabre preservation techniques that have allowed the Russian state to preserve the body 


\section{Modern Russia}

of the father of the Bolshevik Revolution, Vladimir Lenin, in an astonishing condition of undead vitality (Figure 5).

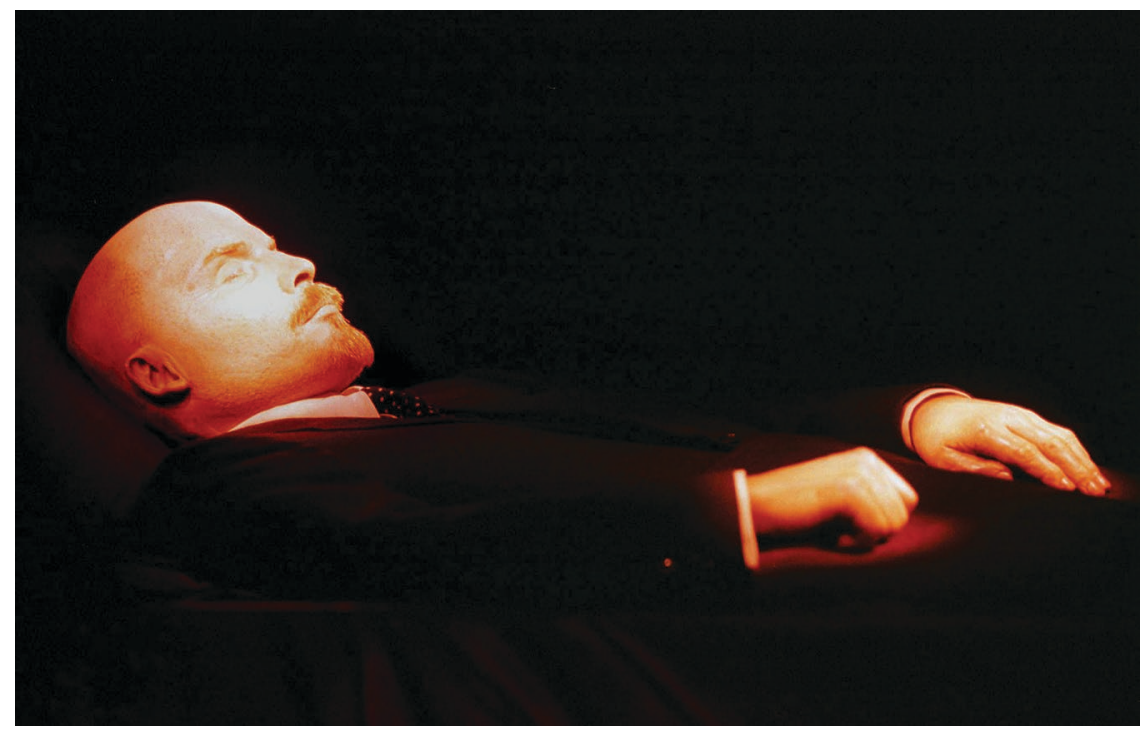

Figure 5: Vladimir Lenin's preserved body on display in the mausoleum on Red Square. Photo credit: Wikipedia Commons

Despite ongoing controversy since the fall of the Soviet Union, Lenin's corpse remains on public display at his mausoleum located at the symbolic center of Russian power, Red Square in Moscow. Since his death in 1924, scholars estimate that "more than 10 million people have visited his glass tomb, viewing a body that appears as fresh as the day he died" [Levy 2015]. According to Andrei Yurchak, who is currently writing a book on the intersections between Soviet and Post-Soviet politics and the Bolshevik leader's "undead" body, the maintenance of Lenin's remains is unprecedented in the human history of embalming, since past efforts, such as mummification, always focused "on preserving the original matter while the form of the body changes" [Hsu 2015]. By contrast, the goal of Lenin's preservation has been the exact opposite, that is, to maintain the original colors of his hair, skin, and lips, as well as the suppleness of his flesh, joints, and limbs [Yurchak 2015]. Over time, this process has required more and more of Lenin's original human material to be replaced by synthetics, such as plastics and injectables [Hsu 2015; Yurchak 2015]. This process gives rise to a richly fascinating paradox, one that has attracted politicians, political commentators, and artists alike. That is, in order for Lenin to keep looking like himself, he must contain less and less of his original body and take on more and more alien matter. This circumstance suggests another parallel with vampires, who also, in order to maintain their own existence, must imbibe more and more biological material from other human bodies. To support the ongoing work of preserving Lenin's 
corpse, an entire research lab was opened during the Soviet period whose sole task was to pioneer new embalming technologies for use on Lenin's body. They ensured that the Soviet people would never have to come to grips with the fact that their beloved leader was no longer among the living. The lab, which, according to Yurchak [2015], actually consists of several laboratories and scientific research groups, remains functional to the present day. It is due to the unceasing efforts of the scientists who work there that Lenin's body does not openly betray any signs of deterioration, but merely appears to be the Bolshevik leader's sleeping form more than ninety years after his actual death.

In fact, the scientists who work on Lenin's undead body do not describe it as preserved at all, preferring instead to emphasize its ultra-lifelike qualities. For example, they view it as a "living sculpture" which is "dynamic, flexible, emergent" [Yurchak 2015: 128]. As Yurchak explains, this maintenance process itself is "not just scientific but also artistic" [Yurchak 2015: 128]. In this connection, it is easy to see how the vampire legend fell on such fertile ground in the Russian political context. Indeed, modern researchers' descriptions of Lenin's corpse form an eerie echo of Jonathan Harker's original description of the undead vampire. In Stoker's novel, when Harker is desperately exploring Dracula's castle in order to find a means of escape, he comes across the coffin which houses Dracula's undead form during the daylight hours. He tells us that "the eyes were open and stony, but without the glassiness of death - and the cheeks had the warmth of life through all their pallor, and the lips were as red as ever. But there was no sign of movement, no pulse, no breath, no beating of the heart" [Stoker 1996: 50]. Apart from the fact that Lenin's eyes are closed, this description could just as easily fit the corpse of the Bolshevik leader. When visitors come to the Mausoleum, they are greeted by the sight of Lenin's completely inert form clothed in a dark suit, his hands still pleasantly flesh-colored with pinkish nail beds, and his lips and cheeks plump, full, and pink. Moreover, Russian state media has both embraced and propagated this interpretation of Lenin's undead body as a constant reminder of authoritarian rule that is specifically vampiric. For example, in 2019 the media outlet Russia Beyond, an English-language publication that is owned by the Russian government state news agency Rossiia Segodnia, published an article in its "History" section entitled "Vladimir Dracula: How Soviet Russia Tried to Create Immortals." This article, which features graphic images of Lenin, a 1916 book cover of Dracula, and Red Square, where his Mausoleum is located, all bespattered with scarlet blood, credits the popularity of Stoker's novel in the early 20th century with the desire to preserve Lenin in as life-like a form as possible. As the author Daniel Chalyan notes, "the idea that a figure of such colossal stature could die was unfathomable" [Chalyan 2019].

These unique similarities between the embodiment of political power in Russia and the vampire have given rise to a modern brand of vernacular belief construction, in which Putin both draws on the strength of the vampiric image, while artists and political opponents themselves make use of the vampire in order to critique his regime. The vampiric image buttresses Putin's political persona and the desire to preserve a strong, centralized government, for it provides a concrete 


\section{The Hunt for an Eternal Legacy: Putin and the Vampire Legend in Modern Russia}

example of how sovereign power may continue in perpetuity, without reference to a physical body that may wither and decay. As Yurchak so elegantly phrases it, the practice of preserving Lenin's body constitutes "nothing other than the material cultivation of the immortal, infallible, perpetually renewed body of the sovereign party - the body that transcended individual mortal bodies of its every member and leader" [Yurchak 2015: 146-147]. Despite the fact that, ever since the collapse of the USSR, there have been calls from both within and without Russia to bury Lenin in the ground, thus knocking him down from his authoritarian pedestal and moving on from the specter of the Soviet past, Putin himself continues to insist that Lenin's preservation is relevant and that his otherworldly lifelike form should remain under glass at the Mausoleum for all to revere. As Yurchak relates, Putin and others believe "'It's too soon to evaluate Lenin's place in history. Let's not succumb to foreign comments. Let's deal with Lenin ourselves" [Levy 2015]. In championing this position, Putin reaffirms his political stance as a defender of the Russian right to self-determination against "bullies" who seek to embarrass Russia for her past. As a result, the decision to keep Lenin on display takes on a larger significance, for Putin is not only staunchly defending strong Russian leaders themselves, but also, the right of the Russian government itself to ensure the legacy of these leaders will continue to be valued, not only by the present day, but also going forward into the future.

Such a reaffirmation of the timeless nature of strong Russian power dovetails with the refuge of immortality that the vampire mythos offers. Indeed, Putin himself projects the image of an immortal leader dedicated to physical exercise. Putin famously retains a youthful, even ageless appearance, likely owing more to modern medical interventions such as Botox injections and facelifts, rather than exercise. These physical attributes strengthen his political sovereignty as well, for they allow him to continue to refuse to say when, if ever, he might cease to run for reelection as President of the Russian Federation. That is, as long as Putin does not appear to get older, it is not incumbent upon him to discuss ceding power to someone else, because the possibility that someday he may age out of the job is never considered. This connection is bolstered by local Russian media, which also reports on the relationship between Putin's sanguine predilections and his youthful bloom of radiant health that is unusually striking for a man in his midsixties. For example, according to a story originally published by the Russian news outlet Republic in 2017, major Russian leaders, such as Putin, his Prime Minister, Dmitrii Medvedev, the Chairman of the State Duma, Viacheslav Volodin, and others, have long favored consuming and bathing in blood from the severed antlers of the Siberian red deer, which is thought not only to confer special healing properties and physical and sexual strength on the user, but also to stop the aging process [Filonov 2017; Pleitgen and Ilyushina 2018].

However, there is another, less positive side to the vampire image in modern Russia. Since Putin ascended to the Presidency in 2000, contemporary Russian artists have weaponized the vampire mythos, harnessing it for their own purposes. In this regard the huge commercial success of Timur Bekmambetov's blockbuster Nochnoi dozor [Night Watch, 2004] proves enlightening exactly 
because of its appropriation of the vampire legend to comment on post-Soviet political and social life in Russia. The film is based on the science fiction thriller Night Watch, the first novel in Sergei Lukianenko's popular six-part series [Lukianenko 1998]. The film begins in 1992 - a year after the fall of the Soviet Union-before moving to 2004 Moscow where a fragile truce exists between the forces of "Dark" and "Light." While members of both groups are considered "others" because they have superhuman powers, they are differentiated in that the Light Ones protect people from the Dark Ones, who gain their power by feeding off humans. The detente between the two factions dates back to the Middle Ages when, locked in battle, the forces realized that their powers were equally balanced; concluding that they would exterminate each other before one side could claim victory, the leader of the Dark Forces, Zavulon, and the leader of the Light Forces, Geser, broker a truce. Moving into the current era, this truce is threatened by the appearance of an all-powerful "Other," a boy who is the estranged son of the film's protagonist, Anton Gorodetskii. While Anton is a member of the Light Forces, his son, Egor, must decide whether to join the "Dark" or "Light"- a decision that will unsettle the balance between the two factions.

The film-which smashed box-office records and earned \$16.3 million in Russia-deals directly with the vampire legend as an allegory for the political forces governing Russia [Goscilo 2007: 223]. The importance of Night Watch should not be underestimated. Serving as a "reference point to interpret political events, post-socialist identities, and even post-communist philosophical questions" the film's vampires, in Stephen Norris' assessment, "served as more than entertaining characters; they also functioned as a mode of cultural discourse" [Norris 2007]. On the one hand, the Light Forces, which Geser leads under the auspices of his position at Gorsvet (the Moscow Light Company), occupy a position aligned with the State. Not only are they government employees working within the city light company, Geser's office also harkens back to the Soviet era with its "oak paneling...allud[ing] to the business style of the Brezhnev period" [Strukov 308]. In contrast to the legitimate authority of the Light Forces, members of the Dark Forces clearly represent the criminal echelon as they are decked out in Adidas tracksuits, gold chains, and cruise around Moscow driving sports carsall telling attributes of the post-Soviet mafia. Viewed in this context, the truce between the "Dark" and "Light" signifies the balance not only between good and evil, but between the state and the criminal world-a truce that Putin himself seems to mediate from the office of the president. In this regard, while the film does not directly reference Putin, it finds the vampire motif particularly apt to describe the major forces fighting for dominance in post-Soviet Russia.

Similarly, the theme of political power takes a biopolitical turn in Victor Pelevin's novel Empire $V$ [2006]. The narrative describes the elite world of vampires and is told through the perspective of 19-year old Roman ("Rama"), who undergoes the transformation from human to vampire. In Pelevin's narrative, humans provide sustenance for vampires, not only through blood, but through bablos, "a concentrate of the vial energy of homo sapiens expended in their frantic pursuit of bliss" [Khagi 2011: 453]. Vampires, accordingly, developed the 


\section{Modern Russia}

techniques to rear humans to produce an unending fresh supply of food source. As one of his teachers explains, "it is we, Rama, who bred people and reared them. For that reason, we must accept them as they are. No one else will ever feel compassion for them" [Pelevin 2016: 75]. However, the vampires of Empire $V$ are at once crueler and more cynical than Stoker's Count Dracula. Pelevin's cadre of hyper-sophisticated vampires believe themselves to be compassionate in their exploitation of humanity.

The hunger for material goods that drives post-Soviet society becomes the very life-force for Pelevin's vampires; in this regard, the text satirizes, in the assessment of Sofya Khagi [2011: 439], "Russia's grotesque infantile capitalism," which Pelevin sees as "a raw form of established commodified existence." As Rama's teacher explains it, the job of the vampire is not to strike fear in the hearts of humans, but to be "an individual of high culture and exceptional refinement, significantly superior in intellectual and physical capacity to the great majority of humankind" [Pelevin 2016: 32]. The vampire accomplishes this through "glamour" and "discourse"- two simulacra of fashion and consumption Pelevin employs to describe contemporary Russian (and global) consumerism.

The novel criticizes, both directly and indirectly, corruption in Russian politics. For one, Rama mentions Putin's political party, United Russia, while taking a cab ride: "I saw an image of two bears on the wall of a building with the sign 'United Russia"' [Pelevin 2016:57]. The poster prompts him to consider the etymology of the word medved' [bear]. He reflects that early Slavs avoided saying the name "bear" for fear they might inadvertently conjure up the animal; in its place they called the animal medved', or one who eats honey. Rama's reflectioncatalyzed by the insignia of Putin's political party - concludes with a different interpretation of "bear":

А что это за настоящее имя, спрашивал я себя, и тут же вспоминал слово “берлога" -место, где лежит... Ну да, бер. Почти так же, как говорят менее суеверные англичане и немцы - “bear”, “bär”. Память мгновенно увязывала существительное с нужным глаголом: бер тот, кто берёт... Всё происходило так быстро, что в момент, когда истина ослепительно просверкивала сквозь эмблему победившей бюрократии, такси всё ещё приближалось к стене с медведями” [Pelevin 2010: 63]

[What's with the actual name, I asked myself, and then remembered the word berloga (bear's den) - the place where it lays...Well right, ber. It's almost the same as what the less superstitious Brits and Germans call "bear," "bär." I immediately linked the noun with the right verb: berone who takes (beret)...It all happened so quickly; the moment of my revelation shown through the emblem of victorious bureaucracy as the taxi kept nearing the wall with the bear on it.] (5) 
Pelevin's wordplay is lost in the English translation, given that Rama connects the Russian verb brat', to take, with Russia's largest political party, United Russia. What he describes as the "victorious bureaucracy," references corruption with the country's major political party and the efforts to silence political dissent in Putin's Russia.

Rama's transformation from human to vampire gives him new insight into Russia's political and social elite. At a critical juncture in his transformation, Rama must prove his worthiness by biting a member of the Chaldeans, a secret society that worships (and serves) vampires. To pass the test, Rama must reveal the deepest, darkest secret of the Chaldean selected to represent the group. Rama successfully outmaneuvers his adversary, the powerful businessman Ivan Grigorievich Semniukov, and exposes, to the shock of all Chaldeans, that their trusted broker is nothing more than a scam artist. "All he has are a couple of brassplate Potemkin firms," explains Rama, and "the truth is that he lives off bribes like any official" [Pelevin 2006: 250-1]. Driven by greed, Semniukov, "cannot keep himself on a level to match the kind of people he consorts with in Davos and Courchevel" [Pelevin 2006: 251]. Rama's revelation shocks the Chaldeans in attendance; given that he passes the test, Rama is subsequently proven worthy to taste bablos. Upon completion of his first degustation, his teacher gives Rama a "commemorative badge for the "God of Money"" with an engraving on the back that reads: "It is not I who must suck it, but all the others. -Count Dracula" [Pelevin 2006: 332]. Pelevin thus adopts Stoker's depiction of Dracula, but reworks it for the Russian context. Stoker's Dracula threatens to revenge himself by making British women his vampire slaves: "Your girls that you love are mine already; and through them you and others shall yet be mine - my creatures, to do my bidding and to be my jackals when I want to feed" [Stoker 1996: 302]. Pelevin, by way of comparison, normalizes the "vampiric nature of money in terms that sound unmistakably Marxist" [Etkind 2009: 646]. In sum, the vampire legend has proven to be one of the more flexible signifiers in Soviet, post-Soviet, and contemporary contexts. Whether in relation to Lenin's undead body housed on Red Square, as an allegory for cultural sovereignty, or in reinterpretations of the Dracula legend, the image of the vampire has offered Russian artists and filmmakers a gateway to interpret the political and social changes taking place around them.

\section{Digital vampirism}

In contemporary Post-Soviet cultural space, the literary text of Dracula from the nineteenth century has now crossed the boundary into the digital realm as well. Internet memes, which, for the purposes of this study also include digitally manipulated magazine covers and digital illustrations of Vladimir Putin as vampire that have gone viral through social media, represent the latest iteration of the Dracula legend. (6) While some of these images and the accompanying stories and viral videos are clearly made for their shock value or sheer ridiculousness, such as the article and video, complete with an anonymous fan-altered vampire 


\section{Modern Russia}

photo on the conspiracy website Disclosetv.com, under the heading "Is Putin a Time Traveler, or a Vampire?" (Figure 6), many others leverage the image of Dracula in order to condemn the actions of the Putin regime.

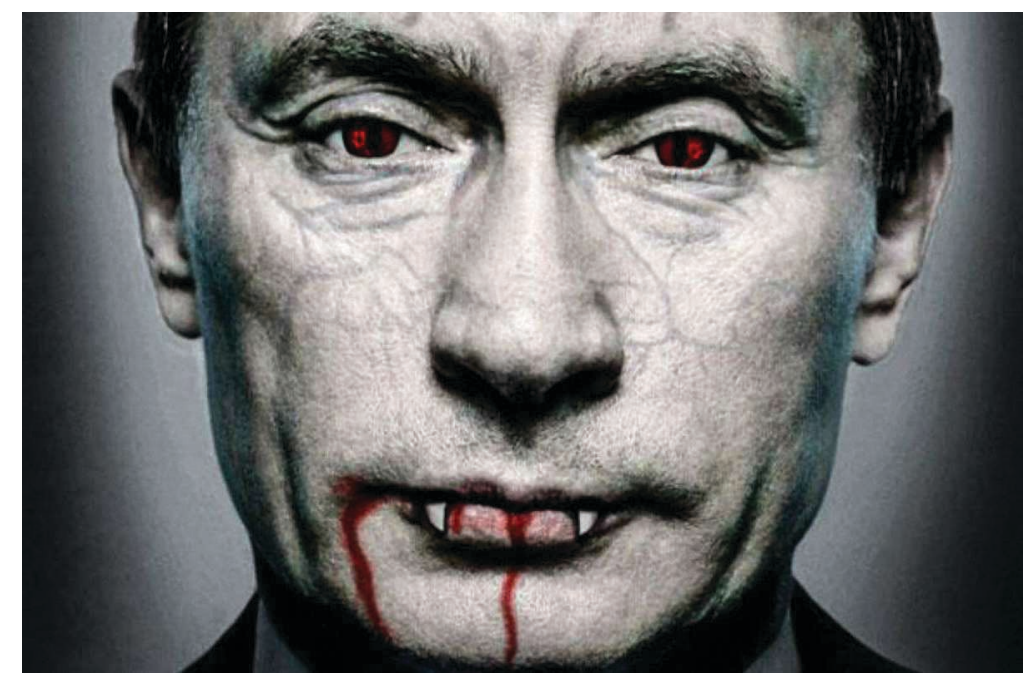

Figure 6. Altered photo of Vladimir Putin from online story "Is Putin a Time Traveler, or a Vampire?"

What is particularly striking about this movement of Putin vampire images is that it is actually transnational, for it provides Slavic cultural stakeholders from all over the world, such as Polish journalists and US citizens of Ukrainian heritage in Chicago, among many others, a way to fight back against Putin's regime. That is, due to the enduring fame of Stoker's Dracula, it offers a supremely recognizable narrative framework within which to criticize Putin and his policies that people in many different countries, not just those who specifically read Polish or live in Chicago's Ukrainian Village, can readily access and understand. The concept of the Internet meme here is vital, because it has the ability to democratize political engagement and protest. That is, anyone with a wireless-capable device, such as a computer, a tablet, or a smartphone, and a basic set of photo editing tools, which are readily available for free on the Internet, can create and disseminate their own vampire-Putin. An even more user-friendly option is available at the Russian meme-generating website "Meme-arsenal." There, visitors can use the ready-made template to create a personalized Dracula-Putin meme in the language of their choice (Figure 7). 


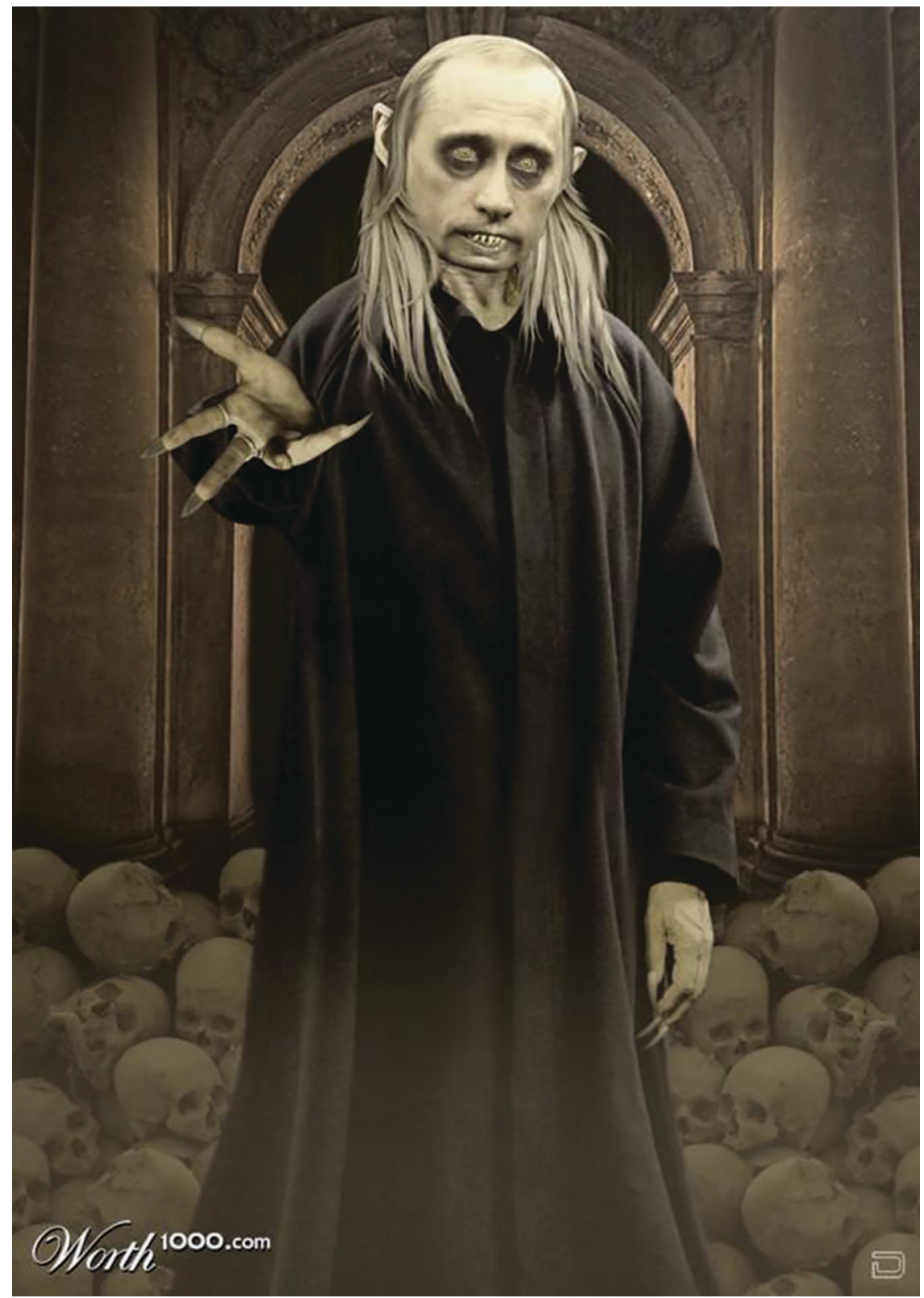

Figure 7. A personalized Dracula-Putin meme from the Russian memegenerating website Meme-arsenal.

This image, with its emphasis on the pointed ears, tapered fingers, and hollowed-out eye sockets, clearly casts Putin in the mold of the vampire from 


\section{Modern Russia}

F.W. Murnau's unauthorized adaptation of Stoker's Dracula into the 1922 Expressionist horror film Nosferatu (Figure 8).

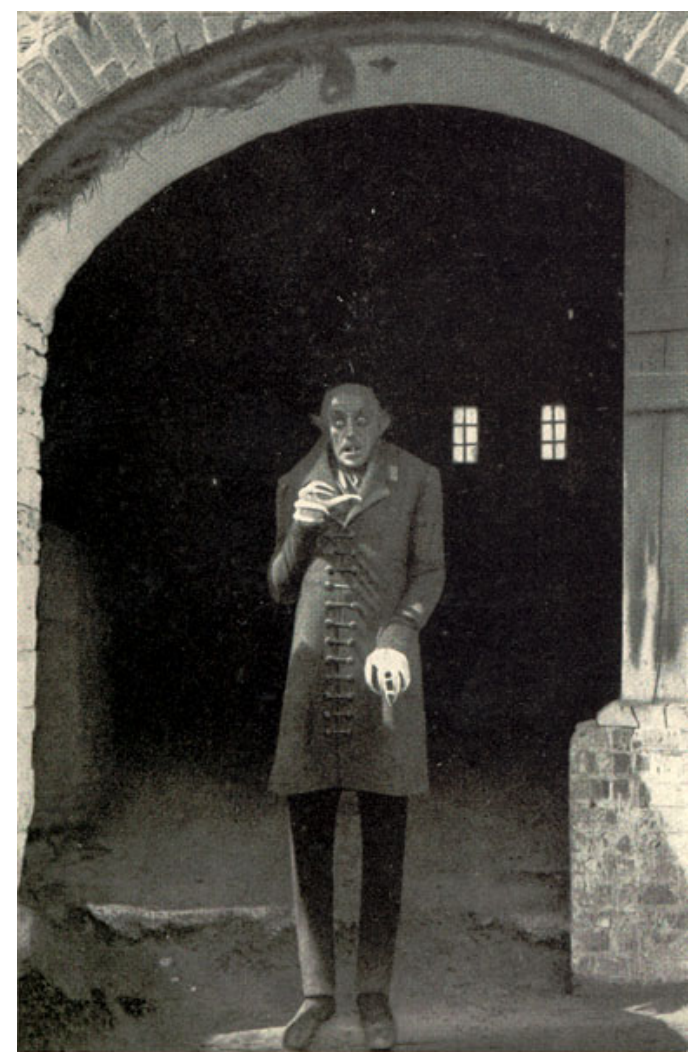

Figure 8. Still shot from F.W. Murnau's Nosferatu (1922). Image credit: Wikipedia Commons.

News outlets with varying budgets and amounts of resources have made use of these technologies. Perhaps even more importantly, any private citizen in possession of the aforementioned devices can access, consume and debate these images of Putin as well. A representative example of this type of protest in journalism which went viral is the cover of the Polish news magazine Uwazam Rze Historia [Uwazam Rze History], from 21 March 2014 (Figure 9). 


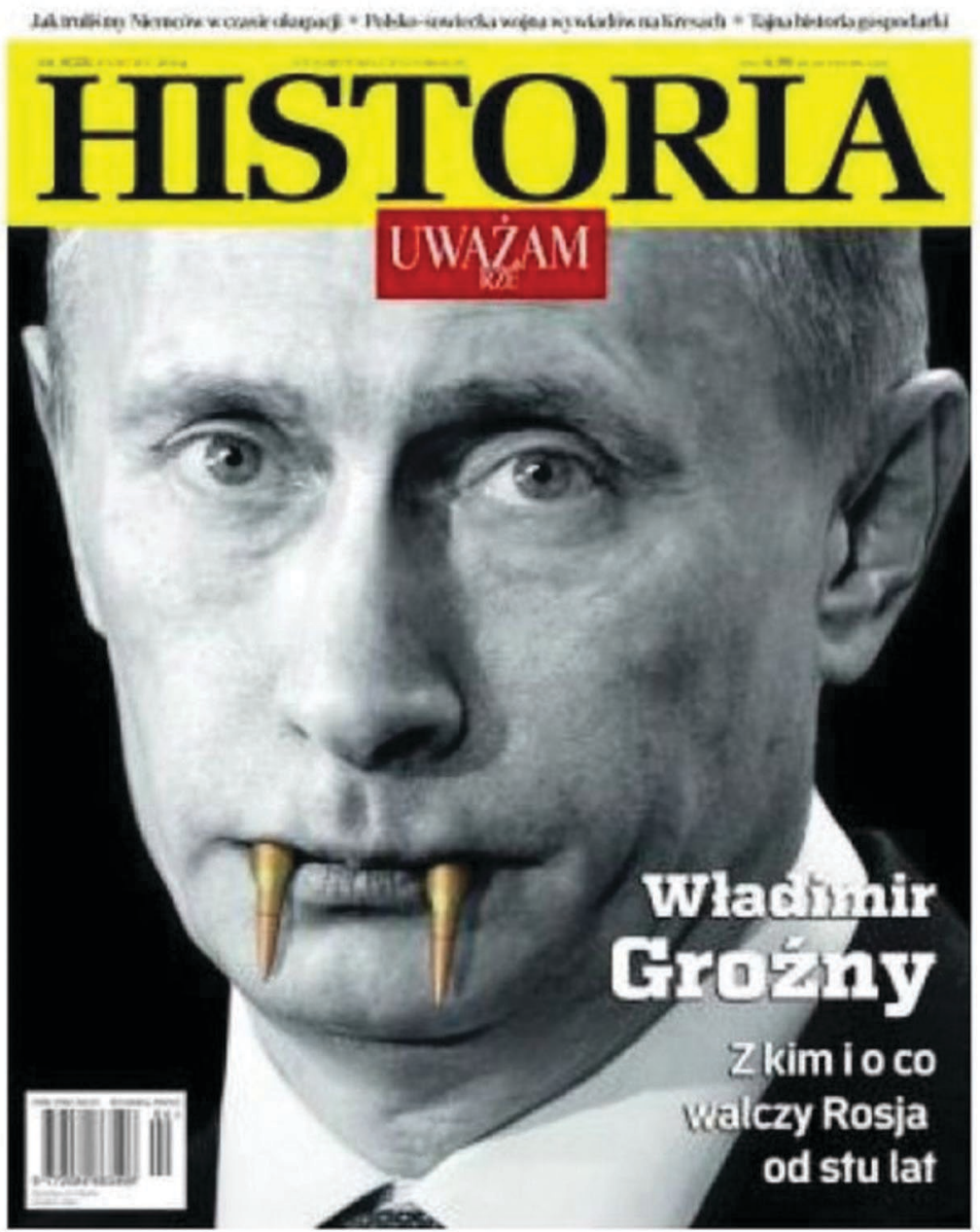

Figure 9. 2014 Cover of the Polish news magazine Uwazam Rze Historia Image credit: Uwazam Rze History.

The cover was published in order to censure the forced Russian annexation of Crimea earlier that month, as well as the war over this territory that is still raging in the Donbas region of Ukraine as a result. The headline says "Vladimir the Terrible" in Polish, but the illustration is clearly meant to evoke Dracula, since it features two full-color fangs inserted into the mouth of Putin, who is shown in black and white. Moreover, the caption underneath Putin emphasizes his immortal nature as a vampire, as it reads in the original Polish, "With whom and with what Russia has fought for a hundred years." However, perhaps the most fertile image of Putin, which countless Internet users have co-opted for their own expressive 


\section{Modern Russia}

purposes, is the famous photo that Time magazine used for the cover of their "Person of the Year" issue, when they honored the Russian president with this award in 2007. This image, which is constantly replenished with fresh interpretations in the world of online memes, is an ideal image for alteration. Not only is it readily available from a plethora of digital sources, owing to the wide readership of Time magazine itself, but also, the composition of the photo makes for an excellent canvas, since it boasts a close-up of Putin's face with a neutral expression and boasts a pale and even skin tone, with clearly delineated facial features. Indeed, it was this very photo that the Polish news magazine Polska Niepodlegta [Independent Poland], available in both digital and print versions, altered and ran as the cover of their 28 July 2014 issue (Figure 10).
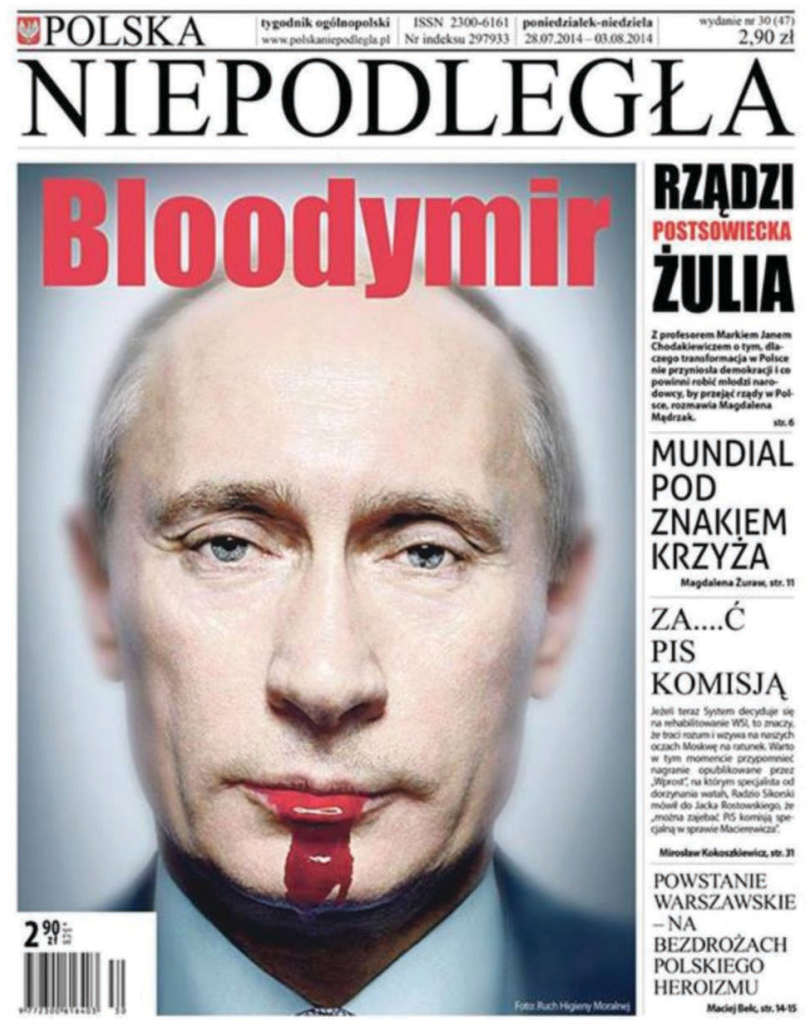

Figure 10. Cover of Polish news magazine Polska Niepodległa. Photo credit: Independent Poland from 2014.

This design protested the actions of Kremlin-backed separatists in Eastern Ukraine, who are widely believed to have been responsible for launching the Buk surface-to-air missile that shot Malaysian Airlines Flight 17 out of the sky, killing 
all 283 passengers and 15 crew members on board only a few days prior, on 17 July 2014. The photo itself features the Time cover shot of Putin but edited so that bright scarlet blood now pools on Putin's lower lip and runs down his chin in a wide rivulet. Moreover, above the photo appears the single-word caption "Bloodymir" in bright red font, which is a sinister-sounding play on words combining Putin's first name, Vladimir, with Dracula's most famous attribute, human blood. Thus, the photo of Putin as vampire is meant as a condemnation of his entire regime.

However, it is not just journalists who have wielded the Dracula paradigm against Putin. Private citizens, too, have co-opted Stoker's narrative in order to convince online audiences of the heinous and unnatural nature of the Kremlin's activities. A representative example of an extended Dracula discourse is an article published in the Ukrainian Magazine Chicago, a biweekly print and online journal, by guest contributor Rev. Myron Panchuk, M.A. The article, which was posted online and also shared through Facebook and other types of social media, is a lengthy comparison of Putin to Dracula [Panchuk 2015]. Original illustrations by the artist Oksana Vaskiv-Kukul that depict Putin as a befanged vampire bat who is silhouetted against a scarlet moon and flies over Red Square at night, with dozens of bone-bright skulls stacked in place of bricks in the walls of the Kremlin, complete the article (Figure 11). 


\section{Modern Russia}

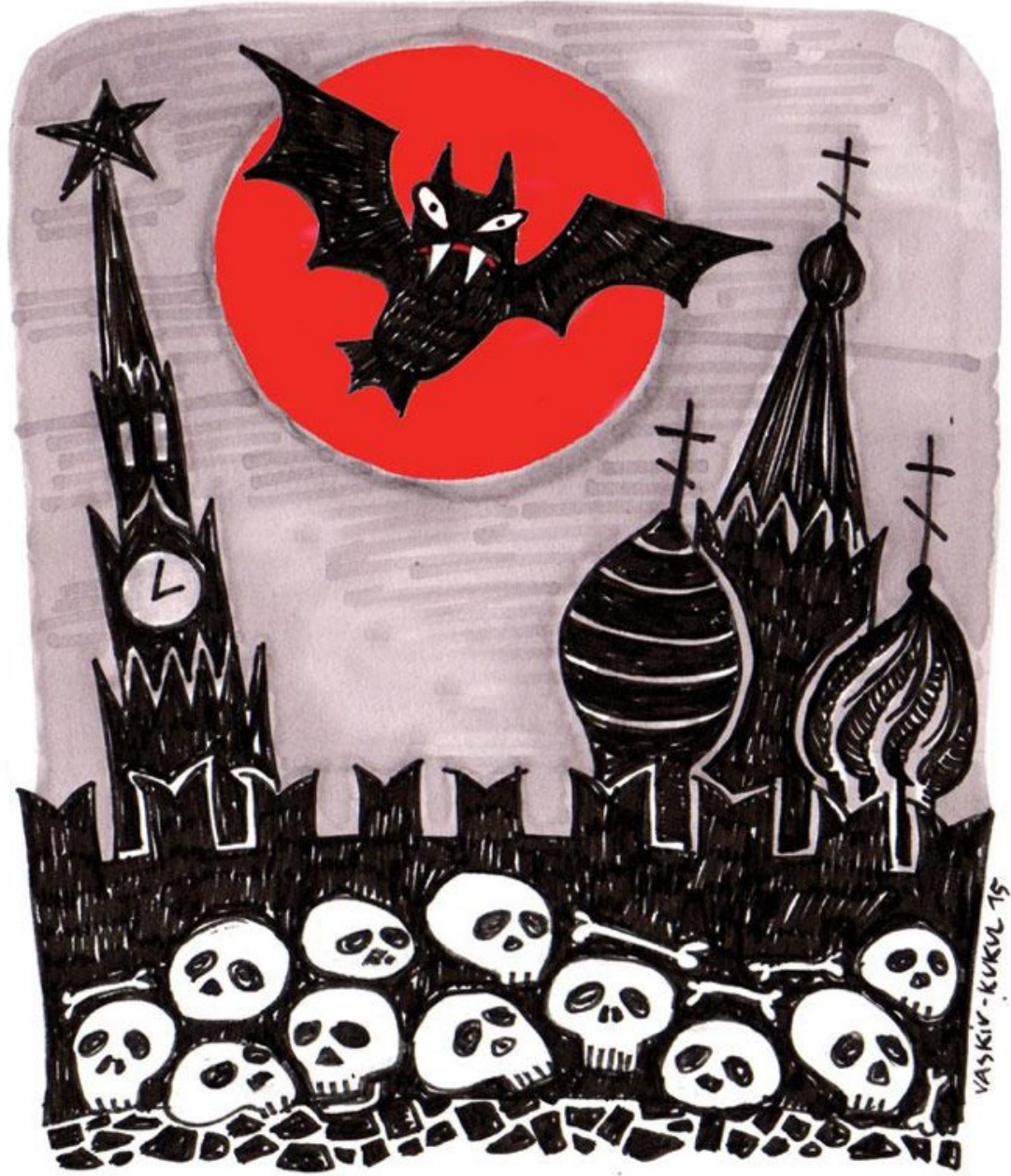

Figure 11. Illustration reproduced courtesy of the artist Oksana Vaskiv-Kukul.

In his text Panchuk draws upon common knowledge of Stoker's tropes, such as the personal advantage that the vampire gains by sucking other creatures' lifeblood and the inability of the vampire to cast a reflection in a mirror, in order to, quite literally, demonize Putin as one who is "bloodthirsty, sinister, and lives outside the boundaries of ethics and morality" [Panchuk 2015]. Having established Putin as the ultimate evil who has sucked the life out of non-Russian ethnic groups in the former USSR, Panchuk then lays the following crimes at Putin's bloody feet: "the genocide of the Chechen people, the terrorist acts in Moscow and Beslan, the invasion of Georgia, the unnatural deaths of 205 journalists, the annexation of Crimea and the military invasion of Donbas" [Panchuk 2015]. Panchuk concludes by invoking the familiar instruments, forever 
popularized by Stoker's tale, that are known to fell vampires: holy water, crucifixes, garlic, and a stab wound to the heart. However, there is one key difference: while they may have worked in Stoker's narrative world-Dracula famously dies by two simultaneous knife blades, one to the heart, the other, to the throat-according to Panchuk, they will not succeed in our post-Soviet era. Instead, we must remain alert and observant, continuing to speak out against the personification of evil, in order to gather the information necessary to defeat a post-modern vampire in the digital age.

Vampire revenge: embracing the image

Both repulsive and seductive, the vampire has attracted Russian writers, artists, and filmmakers because of its rich symbolic potential. Whether in cinema, contemporary fiction, or online memes, the image of Dracula has become a powerful force to comment on Putin's Russia. The different representational possibilities show how contemporary audiences, both in Russia and abroad, have used the monster to express desires and fears related to Putin's political hegemony. This flexibility of the vampire figure to signal different meanings aligns with Jeffrey Jerome Cohen's description of the monster as a "cultural body" that morphs depending on the given moment: "In vampire stories, the undead returns in slightly different clothing, each time to be read against contemporary social movements or a specific, determining event: la decadence and its new possibilities, homophobia and its hateful imperatives, the acceptance of new subjectivities unfixed by binary gender, a fin de siècle social activism paternalistic in its embrace" [Cohen 1996: 5]. The comparison of Putin to a vampire has taken on a multiplicity of meanings that involve a complex reworking of Stoker's Dracula rather than of native traditional narratives that Stoker relied on, in part, to produce this iconic text.

\section{NOTES}

1 For an explication of the vampire as metaphor for Serbian nationalism in the post-Yugoslavia context, see Tomislav Longinović's Vampire Nation: Violence as Cultural Imaginary (2011).

2 The clip in which George H. Bush discusses his successful first meeting with Vladimir Putin dates to June 16, 2001 [User-Created Clip 2018].

3 Predictions made by seers and saints on Russian political triumphs likewise factored in the Soviet period. St. Matrona of Moscow reportedly prophesized Stalin's victory in WWII. (See Rouhier-Willoughby, Jeanmarie and Tatiana Filosofova. 2015. "Back to the Future: Popular Belief in Russia Today." The Changing World Religion Map, Stanley Brunn (ed.). New York: Springer. $1531-1554$.

4 It is worth mentioning that the origin of the surname "Dracula" likely comes from Vlad's father (Vlad Dracul) who was initiated into the Order of the Dragon (Societas draconistarum), a society founded in 1408 by Sigismund of 

Modern Russia

Luxemburg. Other plausible theories for the epithet point to the Latin term draco, which is etymologically connected to the Romanian drac, meaning "devil". Historian Matei Cazacu also posits a third possibility that Dracul could men "devil of a man" as in highly cunning and courageous. See Cazacu and Reinert [2017: xiv].

5 We offer our own translation of this quotation because the segment is omitted from the 2006 English language version of Pelevin's novel.

6 Though she does not discuss vampires or the Dracula myth in particular, Alison Rowley has a fascinating chapter on the Putin meme phenomenon in her recent book Putin Kitsch in America. See Chapter 6, "Putin at Your Fingertips: The Online Presence of the Russian President."

\section{BIBLIOGRAPHY}

Afanasev, Aleksandr. 1973. Russian Fairy Tales, transl. by Norbert Guterman. New York: Random House.

Cain, Jimmie E., Jr. 2006. Bram Stoker and Russophobia: Evidence of the British Fear of Russia in Dracula and The Lady of the Shroud. New York: McFarland \& Company, Inc.

Cassiday, Julie and Emily Johnson. 2010. "Putin, Putiniana and the Question of Post-Soviet Cult of Personality," The Slavonic and East European Review 88(4): 681-707.

Cazacu, Matei. 2017. Dracula, transl. by Nicole Mordarski et. al., Stephen W. Reinert, ed. Boston: Brill.

Chalyan, Daniel. 2019. "Vladimir Dracula: How Soviet Russia Tried to Create Immortals," Cited by https://www.rbth.com/history/329910-soviet-russialenin-blood-vampires. (consulted 20 July 2019).

Cohen, Jeffrey Jerome. 1996. "Monster Culture (Seven Thesis)." Monster Theory: Reading Culture, Jeffrey Jerome Cohen, ed. Minneapolis: University of Minnesota Press. 3-25.

Crouch, Hannah. 2018. "Who is Baba Vanga? List of Predictions from the Blind Mystic." Cited by https://www.thesun.co.uk/news/3371876/blind-mysticbaba-vanga-predicitions-brexit-putin-syria. (consulted 30 July 2019).

Disclosetv. 2016. "Is Putin a Time Traveler or a Vampire?" Cited by https://www.disclose.tv/is-putin-a-time-traveller-or-a-vampire-304740. (consulted 15 December 2018).

Etkind, Alexander. 2009. "Stories of the Undead in the Land of the Unburied: Magical Historicism in Contemporary Russian Fiction." Slavic Review 68(3): 631-658.

Evlampiev, Andrei. 2018. “Запад ужаснули слова Ванги о будущем Путина” [The West is Horrified by Vanga's Statements on Putin's Future]. Cited by https://dni.ru/society/2018/3/19/393684.html. (consulted July 30, 2019).

Filonov, Dmitrii. 2017. Филонов, Дмитрий. “Кровь, рога и бульон. Почему первые лица страны любят оленей с Алтая” [Blood, Horns and Broth. 
Why the Country's Top Officials Love Altai Deer]. Cited by https://republic.ru/posts/84607. (consulted 14 December 2018).

Garza, Thomas J. 2010. "Introduction." The Vampire in Slavic Cultures. Thomas Garza, (ed.). San Diego: Cognella. 1-5.

Goscilo, Helena. 2012. "Putin's Performance of Masculinity: The Action Hero and Macho Sex-Object." Putin as Celebrity and Cultural Icon. Helena Goscilo, (ed.). New York: Routledge. 180-207.

Hsu, Jeremy. 2015. "Lenin's Body Improves with Age." Scientific American. Cited by https://www.scientificamerican.com/article/lenin-s-bodyimproves-with-age1. (consulted 14 December 2018).

Hudson, Dale. 2017. Vampires, Race, and Transnational Hollywoods. Edinburgh: Edinburgh University Press.

Komsomol'skaia pravda, 2003. “Защищают ли Путина колдовские силы?” [Does Putin protect the powers of sorcery?], 14 August. Cited by https://www.kp.ru/daily/23093/5619. (consulted 10 July 2019).

Kononenko, Natalie. 2007. Slavic Folklore: A Handbook. Westport: Greenwood. Leatherdale, Clive. 1998. "Stoker's Banana Skins: Errors, Illogicalities and Misconceptions in Dracula." Dracula: The Shade and the Shadow. Elizabeth Miller, ed. Westcliff-on-Sea: Desert Island Books. 138-154.

Lemon, Jason. 2018. "Trump was 'hypnotized' by Putin and shouldn't meet him one-on-one." Cited by https://www.newsweek.com/trump-hypnotizedputin-shouldnt-meet-one-one-senator-says-1233825. (consulted 17 July 2019).

Lesiv, Mariya. 2018. "Hope for Ukraine, Fall of America, and Putin the Savior: The Supernatural in Ukrainian and Russian Media and Vernacular Contexts." Journal of American Folklore 131(519): 30-52.

Levin, Eve. 1993. "Dvoeverie and Popular Culture." Seeking God: The Recovery of Religious Identity in Orthodox Russia, Ukraine, and Georgia. Stephen K. Batalden, ed. Dekalb: Northern Illinois University Press. 31-52.

Levy, Thomas. 2015. "In post-Soviet Russia, Lenin's body still a powerful symbol." Berkeley News. Cited by https://news.berkeley.edu/2015/05/20/lenins-body/. (consulted 14 December 2018).

Lipovetsky, Mark. 2017. Postmodern Crisis: From Lolita to Pussy Riot. Boston: Academic Studies Press.

Longinović, Tomislav. 2011. Vampire Nation: Violence as Cultural Imaginary. Durham: Duke University Press.

Luk'ianenko, Sergei. 1998. Лукьяненко, Сергей. Ночной Дозор [Night Watch]. Москва: АСТ.

Miller, Elizabeth. 2000. Dracula: Sense and Nonsense. United Kingdom: Desert Island Books.

Oinas, Felix. 1978. "Heretics as Vampires and Demons in Russia," Slavic and East European Journal 22(4): 433-441.

Oinas, Felix. 1998. "East European Vampires." The Vampire: A Casebook. Alan Dundes, ed. Madison: University of Wisconsin Press. 47-56. 


\section{The Hunt for an Eternal Legacy: Putin and the Vampire Legend in 55}

Modern Russia

Panchuk, Rev. Myron, M.A. 2015. "Vladimir Putin: A Reincarnation of Dracula?" Cited by http://ukrainianchi.com/vladimir-putin-reincarnationdracula/. (consulted 15 December 2018).

Pelevin, Viktor. 2006. Empire " $V$ ”. Moscow: Eksmo.

Pelevin, Viktor. 2010. Empire “ $V$ ”. Moscow: Eksmo.

Pelevin, Victor. 2016. Empire V: The Prince of Hamlet, transl. Anthony Phillips. London: Gollancz.

Perkowski, Jan. 1976. Vampires of the Slavs. Cambridge, Mass: Slavica.

Perkowski, Jan. 1989. The Darkling: A Treatise on Slavic Vampirism. Bloomington: Slavica.

Pietsch, Irene. Heikle Freundschaften: mit den Putins Rußland erleben [Fragile Friendships: Experiencing Putin's Russia]. Vienna: Molden.

Pleitgen, Frederik and Mary Ilyushina. 2018. "Russians soak up the 'power' of Siberian red deer blood." Cited by https://www.cnn.com/2018/03/11/europe/russia-deer-antler-bloodintl/index.html. (consulted 14 December 2018).

REN. 2013. “'Нам и не снилось'. 'Ванга. Продолжение'” ['We couldn't have even dreamt it'. 'Vanga. Continuation']. Cited by https://vk.com/video7010758_164660733. (consulted 29 July 2019).

Rouhier-Willoughby, Jeanmarie and Tatiana Filosofova. 2015. "Back to the Future: Popular Belief in Russia Today." The Changing World Religion Map. Stanley Brunn, ed. New York: Springer. 1531-1554.

Rowley, Alison. 2019. Putin Kitsch in America. Montreal \& Kingston: McGillQueen's University Press.

Seckler, Dawn and Stephen N. Norris. 2016. "The Blockbuster: How Russian Cinema Learned to Love Hollywood." A Companion to Russian Cinema. Birgit Beumers, ed. Malden: Wiley-Blackwell. 202-223.

Senf, Carol. 1998. Dracula: Between Tradition and Modernism. New York: Twayne Publishers.

Spargo, Chris. 2015. "Is Vlad a vampire? Conspiracy theorists go nuts over pictures that suggest Putin hasn't changed in 100 years." Cited by https://www.dailymail.co.uk/news/article-3361468/Evidence-suggestsVladimir-Putin-immortal-thanks-Russians-discovering-secret-timetravel.html. (consulted 20 July 2019).

Sperling, Valerie. 2014. Sex, Politics, and Putin: Political Legitimacy in Russia. Oxford: Oxford University Press.

Stoker, Bram. 1996. Dracula. New York: Barnes and Noble Press.

Strukov, Vlad. 2013. "Night Watch." The Russian Cinema Reader: The Thaw to the Present. Rimgaila Salys, ed. Boston: Academic Studies Press. 302-312.

The Late Show with Stephen Colbert. 2016. "Cartoon Trump and Cartoon Putin Make First Joint Public Appearance." Cited by https://www.youtube.com/watch?v=0aU3kX5V634\&t=317s. (consulted 15 July 2019). 
User-Created Clip. 2018. "User Clip: Bush saw Putin's soul," Cited by https://www.c-span.org/video/?c4718091/user-clip-bush-putins-soul. (consulted 2 September 2019).

Worobec, Christine. 2006. "Death Ritual among Russian and Ukrainian Pagans: Linkages between the Living and the Dead." Letters from Heaven: Popular Religion in Russia and Ukraine. John-Paul Himka and Andriy Zayarnyuk, (eds.). Toronto: University of Toronto Press. 13-45.

Yurchak, Alexei. 2015. "Bodies of Lenin: The Hidden Science of Communist Sovereignty." Representations 129: 116-157. 